University of St. Thomas, Minnesota

UST Research Online

Summer 2020

\title{
The Architecture of Narrative Reciprocity in Ali Smith's HOW TO BE BOTH
}

Mary Elizabeth McCartney

University of St. Thomas

Follow this and additional works at: https://ir.stthomas.edu/cas_engl_mat

Part of the English Language and Literature Commons

\section{Recommended Citation}

McCartney, Mary Elizabeth, "The Architecture of Narrative Reciprocity in Ali Smith's HOW TO BE BOTH" (2020). English Master's Essays. 31.

https://ir.stthomas.edu/cas_engl_mat/31

This Essay is brought to you for free and open access by the English at UST Research Online. It has been accepted for inclusion in English Master's Essays by an authorized administrator of UST Research Online. For more information, please contact asle4660@stthomas.edu. 
The Architecture of Narrative Reciprocity in Ali Smith's How to Be Both

by

Mary Elizabeth McCartney

A Master's Essay submitted to the faculty of the Graduate Program in English in partial fulfillment of the requirements for the degree

Master of Arts in English

University of St. Thomas

Saint Paul, Minnesota

August 2020 


\section{Acknowledgements}

First and foremost, I would like to extend my deepest gratitude to my advisor, Dr. Emily James, for her enthusiasm, guidance, and unwavering support. I will be forever grateful for her assistance on this project and her mentorship throughout my graduate studies. Thank you for always encouraging me to chase the spark.

Special thanks to my review committee members, Dr. Alexis Easley and Dr. Todd Lawrence, who have supported me throughout my graduate career and whose feedback on my essay was invaluable.

Finally, my sincere appreciation goes to my family and friends, who now know more about postmodernism than they ever cared to know. Thank you for believing in me. 


\begin{abstract}
To write a book is to create a dwelling. Ali Smith's novels are equal parts narrative and blueprint in the sense that they usher the reader into spaces, homes, habitats, and residences. Thus, an author is surely an architect—someone who designs and plans stories on top of storiessomeone concerned with form and function, aesthetic and purpose. Smith's 2014 novel How to Be Both abounds with images of homes and roofs and doors. This essay is interested in architectural and literary thresholds, thresholds that welcome movement and exchange. Such spaces facilitate a type of narrative reciprocity between the novel's two sections. Smith thus expands the concept of the traditional frame narrative and creates what I call a reciprocal frame narrative focused on exchange instead of embeddedness. I explore the architecture of and in How to Be Both to better understand the connections between the two protagonists, George and Francescho.
\end{abstract}


"Edges are magic, too; there's a kind of forbidden magic on the borders of things, always a ceremony of crossing over, even if we ignore it or are unaware of it." - Ali Smith, Artful

"But when the slates came off, extravagant / Sky entered and held surprise wide open." - Seamus Heaney, "Skylight"

To write a book is to create a dwelling. Ali Smith's novels are equal parts narrative and blueprint in the sense that they usher the reader into spaces, homes, habitats, and residences. Thus, an author is surely an architect—-someone who designs and plans stories on top of stories - someone concerned with form and function, aesthetic and purpose. Smith is one such architect, and her 2014 novel How to Be Both abounds with imagery of homes and walls and roofs. Architects and authors divide buildings into rooms and books into chapters, yet the boundaries, or walls, of How to Be Both are much less defined. The novel is divided into two parts: one focused on a contemporary English teenager (Georgia, known as George) and the other on a fifteenth-century Italian painter (Francescho). Both sections are titled "One," and the order of the two stories changes depending on the reader's copy of the novel. The two sections are relatedly porous: each echoes sentiments from the other; George and Francescho fluidly move between sections and timelines. (For example, Francescho sees visions of George, and George studies Francescho's art.) Smith connects these two stories with architectural language, and readers cross the threshold from one room in the novel to another when they finish the first section. Since my edition features George's narrative first, the following quote led me into Francescho's story: "This is the point in this story at which, according to its structure so far, a friend enters or a door opens or some kind of plot surfaces" (155). This passage implies that the plot of the novel is lost without this junction - this open door. Though a boundary between stories exists, Smith ensures readers and characters can cross it; but thresholds are by nature contradictory. As literary critic Victoria Rosner argues, "The threshold both creates difference 
and collapses it" (62). Thresholds connect and separate; they are fixed but encourage movement. I am most interested in this movement, in literary and architectural thresholds that promote a type of exchange. Such ephemeral spaces, as Allan Johnson contends, "[present] the reader with a portal—with Alice's rabbit hole—of narrative magic" (414). ${ }^{1}$ Indeed, thresholds are often symbolic, magical spaces. By using the metaphor of an open door between stories, Smith constructs the novel with architectural framework, and readers are left to ponder what passes through this open door. At the same time, the phrase "according to its structure so far" indicates that the framework is flexible.

Scholars like Ulrike Tancke and Patrick O’Donnell have examined the function of architecture in Smith's earlier novels. ${ }^{2}$ Yet, the conversation has tended to focus on these structures as a way to frame another discussion. To illustrate, O’Donnell argues that Smith uses temporary spaces such as hotels or vacation homes to discuss the role of the stranger. Few scholars have taken a nuanced look at the symbiosis between structures and narratives, and fewer still have explored such relationships in Smith's later works. Reading How to Be Both, for instance, scholars have largely focused on two-dimensional art forms instead of threedimensional structures and space. Aesthetics are key to Milly Weaver's argument that "the visual world permeates through Ali Smith's texts" by means of photographs, paintings, and digital technology (527). One exception to these patterns is Ben Davies, who studies the structure of the

\footnotetext{
${ }^{1}$ Johnson examines thresholds in the work of Virginia Woolf, who is renowned for writing about threshold spaces. For instance, Johnson discusses the removal of doors in Mrs. Dalloway. In his book Architecture and Modern Literature, David Spurr similarly examines the symbolism of windows in Woolf's work. While not the topic of this essay, the connection between thresholds in the work of Woolf and Smith is exciting material that deserves further analysis.

${ }^{2}$ Tancke, Ulrike. "Narrating Intrusion: Deceptive Storytelling and Frustrated Desires in The Accidental and There but for The." Ali Smith: Contemporary Critical Perspectives, edited by Germanà Monica and Emily Horton, Bloomsbury, 2013, pp. 75-88.

O'Donnell, Patrick. "'The Space That Wrecks Our Abode': The Stranger in Ali Smith's Hotel World and The Accidental." Ali Smith: Contemporary Critical Perspectives, edited by Germanà Monica and Emily Horton, Bloomsbury, 2013, pp. 89-100.
} 
home in Smith's 2011 novel There but for the. Because the novel is non-linear, Davies argues that the reader is "invited to dwell on and in the very textuality of There but for the, a text whose mode of being is far from straightforward, fixed, or stable" (515, emphasis mine). As in Davies' formulation, I propose that readers likewise "dwell on and in" the narrative structure of How to Be Both. Readers are encouraged to examine the architecture of the characters' homes, as well as the architecture of George's and Francescho's respective stories. How can architecture and narrative inform one another ${ }^{3}$ I propose that thinking about the novel architecturally gives readers a key into the text.

This essay explores how Smith builds and breaks architectural frameworks in order to expose their narrative corollaries in How to Be Both. I examine the novel's structures vertically, focusing on the function of ceilings, attics, and roofs ${ }^{4}$ Both George and Francescho notice the roofs above their heads and fantasize about these structures collapsing so that they might better appreciate the sky above. ${ }^{5}$ What does it mean, then, that they desire to dismantle their homes? Smith conflates distinctions between stories and dwellings in order to highlight the need for space-literal space to grieve, or privacy, and metaphorical or narrative space to grow beyond the confines of the house. My essay imagines the roof as a threshold - a transitional boundary that urges readers to look down into the residence and compels characters to look up past it. In the spirit of creating space and removing boundaries, Smith designs multiple narratological

\footnotetext{
${ }^{3}$ There is a rich conversation about these interdisciplinary possibilities. For more information, see: Charley, Jonathan, editor. The Routledge Companion on Architecture, Literature and the City. Routledge, 2019. Sioli, Angeliki, and Yoonchun Jung, editors. Reading Architecture: Literary Imagination and Architectural Experience. Routledge, Taylor \& Francis Group, 2018.

${ }^{4}$ My essay explores references to collapsing ceilings in the novel. While Francescho paints walls instead of ceilings, the novel's focus on art and vertical spaces may be an allusion to the Sistine Chapel. Francescho paints both "angels" and "blue sky" as part of his mural $(165,249)$. Thus, it is perhaps not a stretch to argue that lofted spaces can be read as an almost sacred symbol-a connection between this world and the next, between the known and the unknown.

${ }^{5}$ In a review of the novel, The New York Times suggests that George's name implies other "glass-ceiling-shattering Georges, Eliot and Sand" (Benfey). George's mother, Carol, was a feminist and an activist. Therefore, while this essay focuses on the collapse of the architectural roof, there is an allusion here to the glass ceiling as well.
} 
dimensions within the novel. By which I mean, the two narratives can stand on their own, but they are also reciprocal and mutually entangled. Each story can also be read as an extension or embedded feature of the opposite tale. Francescho's story, for example, can be read as a sovereign, finite, enclosed narrative on the one hand, or, on the other, a history that George has carefully crafted - a narrative embedded in George's imaginative world.

Scholars and students alike are familiar with the frame narrative, or "story within a story," a narrative technique so prevalent that it reaches from Shakespeare's "Pyramus and Thisbe" to popular films like The Princess Bride. Frame narratives imply a hierarchy or primacy: the first story is used to set the stage for an embedded tale. In many cases, a character tells another character a story. The narratives are nested, like layers of an onion; one must encounter the first narrative (or layer) to discover the second. Smith stretches this concept into a postmodern framework: instead of embeddedness, she creates narrative reciprocity and exchange. Each story sets the stage for the other, and neither can be understood as primary or central. In this way, she creates what I call a reciprocal frame narrative. Francescho's narrative is rich with clues about George's, and vice versa, as if each is simultaneously a story and a key to its complement. With these inventive wormholes between narratives, worlds, and even centuries, Smith plays with intertextuality within a single text. ${ }^{6}$ Although there is much to be said about both sides of this exchange, this essay focuses on what it tells us about George, arguing that such a reciprocal and fluid interchange allows readers to better understand George's grief and coming-of-age struggles. In his narrative, Francescho proposes a grieving process through the language of architecture - and specifically through the language of roofs. This Renaissanceera scene contextualizes George's twenty-first century fascination with her leaking ceiling and

\footnotetext{
${ }^{6}$ Granted, due to its unique publishing format, it is a text that is available in two versions.
} 
her struggle to overcome the death of her mother. To understand this intertextuality, we must first understand each narrative separately. Therefore, this essay begins in George's domain, looking closely at the representation of roofs and attic spaces. We then proceed to Francescho's storyline, examining how rooflessness might liberate memories. The last section of the essay encourages readers to walk to and fro between these two rooms, and narratives, appreciating their rich reciprocity.

\section{The complexities of vertical space}

George inhabits an attic bedroom "in the loft bit of the house," symbolizing her place at the top of the household (11). George's alcoholic father cannot ascend his grief after his wife dies, and he even has difficulty maneuvering beyond the first floor of his home. In one scene George's father is out drinking and she "decided to wait for him in case when he gets home he can't get up the stairs by himself" (39). Thus, George navigates the steps of the household hierarchy in ways her father cannot; once her mother, Carol, dies, she must become the caregiver for her father and younger brother. As a result, George is literally and figuratively atop the household. The demands of her family life necessitate a space she can call her own, and she uses her attic bedroom as both a retreat from domesticity and a space to grieve her mother away from her family. The novel, then, asks us to consider the function of George's bedroom and why Smith places her at the top of the house.

The lofted bedroom offers George protection that other spaces in the home cannot. George restricts access to her emotions by concealing her grief - in her bedroom and in her thoughts. This private space is necessary, as it is the only retreat offered to George. The attic, according to environmental psychologist Perla Korosec-Serfaty, affords its occupant a certain distance from the larger structure - a distance that "means being a little apart, a little outside the 
house, in a space traditionally considered secondary" (310). Away from the customary living space, George can openly mourn her mother. As one example, she has an "arrangement of photographs above the pillows on the bed of [her] mother as a woman, a girl and a child and even a very small black and white baby" (124). These snapshots suggest George is studying the trajectory of Carol's life, yet the progression from infancy to adulthood is reversed (i.e., woman to girl to child to baby), highlighting that George can only look backwards on her mother's experiences. There will be no new photographs of Carol. Moreover, the placement of these images above her pillow ensures George sees them every night before going to bed. It is important that this grieving takes place away from the gaze of George's father, who is emotionally absent; George attempts to grieve by herself. Accordingly, this lofted room is paradoxical in nature - while it provides George a private space to grieve, it also encloses this grief in one area of the home. George's room, then, is both freeing and restricting. This contradiction makes space one of the many examples of duality in the novel.

Dwelling in her lofted bedroom becomes unbearable for George, who secretly hopes the roof will collapse. In an enlightening dive into etymology, David Spurr contends the modern meaning of the word dwell "contradicts what the word has come to mean" (53). As he observes, "To $d$ well comes from the Old English $d w e l l e n$, meaning 'to...be hindered"” (53). Thus, a home houses tension-it shelters and stifles. One way to escape this tension is by disassembling the roof. Consider the colloquial phrase "to vent." To vent to another person means to release great swells of emotion. This logic can also be applied to ventilating an enclosed space, such George's room. As Smith writes:

George's room is in the loft bit of the house and since they had the roof redone last summer it's had a leak in it at the slant at the far end. [...] George hasn't said anything about it to her father. The roofbeams will rot and then the roof will fall in. She wakes up 
with a bad chest and congestion in her nose whenever it's rained, but when the roof

collapses inward all the not being able to breathe will have been worth it. ${ }^{7}$ (11-12)

The rotting roof will disintegrate until nothing is left to enclose George. Once the roof deteriorates, George's bedroom will open to the sky, allowing her grief to escape. Yet, markedly, the roof must rot and organically decompose for this spatial freedom to occur. George's breathing is impaired by the damage, suggesting a mind/body divide and indicating the collapse will be corporeal. In short, in order to free George's spirit, her body must suffer. The novel, then, implies the roofed home can only protect the physical self.

Significantly, George conceals her rotting ceiling from her father. Why does she keep this secret? Most likely because her father would fix the leak, and George's emotions would remain trapped in her bedroom. The irony, of course, is that George's father works for a roofing company and operates a camera that allows him to inspect enclosed spaces. He examines other people's roofs, but due to the hangover of grief he does not know what is happening under his own. Korosec-Serfaty maintains that an attic is an "intimate" place that "only the dweller is thoroughly familiar with" (312). While George traces every crack in her ceiling, she knows that “her father never comes into her room. He has no idea it is happening. With any luck he won't find out until it's too late" (12). George's father neglects the leak in the ceiling as well as his daughter's grief, and George wishes to keep him in the dark. As such, in a book about dissolving boundaries, Smith builds a divide between George and her father, which allows George to remain in control of her own (limited) space. George needs privacy to grieve, but also to imagine a world that differs from her father's. Accordingly, I posit that Smith suggests a kind of freedom

\footnotetext{
${ }^{7}$ With Smith's keen ear for allusion and wordplay, the use of the word "slant" may be a reference to Emily Dickinson's "Tell all the Truth but tell it slant-." This allusion is especially fitting, as George hides the truth about her ceiling and her grief from her father. The reference also suggests Dickinson's poem "There's a certain Slant of light," which connects light to grief.
} 
George can only grapple with away from her parents and her childhood home. This freedom, however, cannot remain locked in the attic.

While George's father is unwelcome in her bedroom, the same is not true for Helena Fisker. Helena-George's friend and romantic interest, nicknamed $\mathrm{H}$-has no memories of Carol. Consequently, H's grief will not swarm the space. Quite the opposite, in fact: H only offers support. She visits George at home, and George immediately shows her the collapsing ceiling:

George takes her over to the bookcase and shows her the leak and the rain dripping every few minutes on to the cover of the top book on the pile.

At some point, George says, this roof will stave in.

Cool, Helena Fisker says. You'll be able to look directly out at the constellations.

There will be nothing between me and them, George says. (68-9)

This conversation is significant for two reasons. First, it reveals that $\mathrm{H}$ is George's sole confidant. George tends to hide from others - walking out of a therapy session with Mrs. Rock to make a phone call, camouflaging herself from her brother in the garden, keeping her father out of her room. There is no need to hide with H. In this way, Smith signals to readers that George and H's relationship is significant. Second, this exchange reiterates the roof as a boundary between domesticity and nature. George initially claims that rain will flood her room once the roof collapses, noting the room will be susceptible "to all this rain, the amount of which people on TV keep calling biblical" (13). Yet, instead of rain, this scene with H correlates George's bedroom with the night sky, and the reader's gaze is guided upwards. Rooflessness consequently shifts from flooding to expanded horizons, from water to stars, from earth to sky. Smith, whose prose is haunted by ghosts and spectral figures, encourages readers to consider what exists beyond the limits of home. To put it another way, this conversation foreshadows (or echoes, depending on 
your copy of the book) Francescho's presence in George's narrative, as Francescho observes George from a liminal state between this world and the next, floating between the earth and the heavens. Removing the roof is effectively removing another boundary between the two characters. However, George's playful language muddies our understanding of the roof's fate. I would like to momentarily draw attention to the word "stave" in the passage above. Considering Smith's aptitude for wordplay, this confusion between "cave" and "stave" is surely intentional. Stave can be read as a verb meaning "to crush inwards" but it can also be read as a noun meaning "a vertical wooden post forming part of the framework of a building" ("Stave, v." and "Stave, n.1.”). Since How to Be Both so deliberately pushes back against binaries, it is only fitting that Smith would find a word that means both. This contranym again highlights architectural tension-tension between structure and collapse. The novel, then, urges readers to question the outcome of the roof.

H embodies rooflessness. She walks to George's house "through the rain with no hat or hood or umbrella" (68). She is unabashedly open to the elements, and she encourages George to be open as well. At one point, $\mathrm{H}$ takes George to the top level of a car park, "which is the roof of the car park and is open air, open to the sky, its concrete flooring wet from the rain and shining under the car park lights" (73). The car park provides no shelter from the weather and allows the girls to view the lights above - the two main reasons George yearns for her roof to collapse. Away from her home and enclosed bedroom, George becomes "wild" and zooms across the car park on a trolley - even though "she isn't the kind of person who usually does something like [that]" (75). My point is that George comes out of her shell in this new space. It is the scene in which she is most unencumbered. Yet, why does this moment of freedom occur at a car park - at such an ugly, utilitarian structure? Architects call spaces like this (e.g., malls, airports, parking ramps) “junkspace.” Spurr explains that junkspace can be problematic for authors: 
Architectural forms of the past are more conducive to narrative form, partly because of the richness of their symbolic associations and partly because each of these forms, as well as each concrete instance of it, has a history of its own. The building mediates between the present and the past, and this mediation itself serves as a kind of larger narrative to the narrative proper of a novel or short story. In the case of junkspace or the non-lieu, however, there is no mediation, no history to which the fictional narrative can adhere.

Smith repurposes these discarded spaces and turns them into significant settings in her novels, and in doing so, she encourages readers to think differently about the value of space. ${ }^{8}$ Relative to this essay is what Spurr says about junkspace and history. Like frescoes, houses accrue layers. In other words, since families often remain in the same home for stretches of time, the house holds a certain history. A kitchen, for instance, may be remodeled, or a nursery may change into a child's room which may change into an adolescent's room. Junkspaces can lack this complex past, these layers, this emotional connection. George therefore must escape the private, domestic sphere entirely to find freedom. At the car park, she is permitted to focus on the present moment, as there is no history to build upon. Furthermore, since the car park lacks a roof, George and $\mathrm{H}$ are open to the sky - to new histories and possibilities and opportunities to be wild. ${ }^{9}$

Moreover, if $\mathrm{H}$ represents rooflessness, then perhaps the roof symbolizes another boundary - a boundary between interior and exterior desire. One could argue that by longing for

\footnotetext{
${ }^{8}$ As noted in my introduction, Smith explores temporary spaces like hotels in her earlier work, which Patrick O'Donnell examines in “"The Space That Wrecks Our Abode': The Stranger in Ali Smith's Hotel World and The Accidental".

${ }^{9}$ There is a literary history of patriarchal control in roofed attic spaces. Women are often placed "out of the way" in these spaces, stifling their freedom under the roof of the patriarchy; the only hope of autonomy is breaking out of the confining room. Examples include Bertha Mason from Jane Eyre (the namesake of Gilbert and Gubar's The Madwoman in the Attic) and the unnamed woman in Charlotte Perkins Gilman's The Yellow Wallpaper. The attic becomes a rational space for men to place these "madwomen." By focusing on unroofed spaces, like the car park, George reaches for freedom.
} 
the roof to collapse, George wishes to dissolve the boundary between heteronormative binariesbetween what is expected in her home and what is possible elsewhere. George craves the freedom that $\mathrm{H}$ has to explore her sexuality. While she is attracted to $\mathrm{H}$, she never acts upon her feelings. Smith explicitly notes that the girls do not kiss, though they lay next to each other and "stare at the ceiling" $(122,86)$. In this way, thinking about rooflessness and enjoying each other's company is a form of intimacy. In another scene, $\mathrm{H}$ grabs ahold of George's hand, but George's father interrupts and gives them a disapproving look. H leaves George's house and the light she brings fades rapidly: "When $\mathrm{H}$ goes home at eleven George literally feels it, the house becomes duller, as if all the light in it has stalled in the dim part that happens before a lightbulb has properly warmed up. The house becomes blind as a house, as deaf as a house, as dry as a house, as hard as a house" (76). This playful passage employs the character-as-dwelling metaphor. The "house" becomes blind, deaf, dry, and hard, but it is George who feels it. George becomes the house, and her senses (touch, sight, and sound) fade when $\mathrm{H}$ leaves, as if she was hyper-aware when $\mathrm{H}$ was next to her. Finally - and perhaps most significantly - we once again see H (and rooflessness) connected to rain and light. When she leaves, the house becomes dry and dim, and the roof dutifully shelters its occupants from the elements. The novel, then, privileges wildness and weather over the controlled comforts of home, as if urging the characters to feel their mortality, to feel the pull of the wider world.

Rooflessness ultimately represents emotional freedom in George's storyline. Smith features an adolescent girl navigating loss and romantic love, possibly for the first time. These complex experiences demand space-space to think and feel and express oneself. George cannot explore new emotions when she is managing her household, worrying about her father and her younger brother. As I discussed earlier, George's bedroom is a respite, but it is also a finite, confined room. As a result, George daydreams that after the roof opens, "the structure of the 
house will begin to shift, like it ought" and she "will be able to lie every night in bed watching the black sky" (15). Smith thus reiterates a key dimension of rooflessness: space. The black sky signifies a vast open space and strengthens the presence of nature in the novel. At the same time, it becomes a canvas for stars and organic light - a true, wild light instead of artificial illumination. Hence, Smith implies that George needs space and light to imagine a life in which she can focus on her own happiness. Moreover, the word "ought" implies that George has a right to this space, this emotional freedom.

\section{Memory and "the open roof of me"}

As one of the many parallels in the novel, both George and Francescho are distraught with grief. Like George grieves her mother, Francescho grieves his father. ${ }^{10}$ Smith uses the dwelling-as-self trope to frame Francescho's grief, and Francescho conflates his body with a residence made of bricks and rooftiles. Francescho inherits this aptitude for architecture from his father. Most obviously, these traits relate to his father's profession. As a bricklayer, he spends his days building walls; as a painter, Francescho spends his life adorning them. He also served as his father's apprentice. Francescho's identity, then, is figuratively constructed by interactions with and recollections of his father. One memory is particularly painful, as Francescho admits, "I had a memory of my father from not long before he died that I could not bear" (277). This memory replays Francescho's visit home after three years away, during which he mistakes an elderly "gypsy or wood dweller" for his father (287). He returns to find an "old man in torn cloth pulling

\footnotetext{
${ }^{10}$ In an act of radical and imaginative historiography, Smith rewrites the history of Francesco del Cossa, imagining the painter as a woman who passes as a man to pursue a painting career. After much deliberation about Francescho's ambiguous gender identity, I have used he/his/him pronouns for Francescho according to my reading of the character's preferences - not the historical person who has been fictionalized. At the same time, one could argue for she/her/hers pronouns, as Francescho's father initially suggests and encourages this change in identity.
} 
by hand a cart loaded with the dregs of household stuff," and the townspeople take this man's possessions without paying him (287). From Francescho's vantage, his father has become homeless in his absence and forced to sell remnants from their household; the brickmaker's world has been turned upside down without his son. In reality, Francescho returns home and "[his father] was there, he was fine" (287). Still, he cannot shake the feeling that he abandoned his father, and these recollections drive him to participate in a ritual to Mnemosyne, the Greek memory goddess.

Francescho is initially unsure if he wants to lose his memories and, thus, become "roofless." Virginia Woolf - if not foremost among Smith's models, then certainly high on the list—once called the attic "the brain of the house," which is a useful metaphor for better understanding Francescho's memory ritual (Rosner 69). Since the attic is often out of sight, it is not uncommon for the space to be unkempt. Indeed, Korosec-Serfat contends that attics are "identified with accumulation, stockpiling and reserve supplies" (309). Francescho stockpiles memories, many of which are haunting, and he must open his mind to become roofless. I am not contending that Francescho is closed minded; in fact, he is quite the opposite. Rather, I am suggesting he is unable to manage memories he has tried to forget. Francescho anxiously clarifies the ritual with his friend Barto by stating:

And then my memories fly off the top of me, I said, like someone putting a ladder against my walls if I were a house and climbing up on to the roof of me where all the things I remember are neatly laid like rooftiles, the first under the next under the next under the next. And then that someone jemmies each tile off, throws it down to the ground and doesn't stop till the rafters are bare. Yes? (282)

The verbs in this passage gesture toward Francescho's lack of control. Someone else "puts" a ladder against him, "climbs" on top of him, "jemmies" the tiles off, and "throws" them to the 
ground. These verbs are forceful, as if Francescho has no choice, no agency, in his own remembered life. Put simply, the memories control Francescho, not the other way around. In addition, while his memories are organized and "neatly laid like rooftiles," the passive verb suggests that here, too, Francescho has no agency. That is, he does not say "I neatly lay my memories like rooftiles." He is worried his memories will fly away, as if they are caged birds waiting to be released and he cannot contain what will happen if his roof is opened. Smith indicates that amid his grief, Francescho cannot so easily manage his thoughts.

The memory that Francescho cannot bear stems from visiting a home that has become unfamiliar. Francescho journeys to his hometown to visit his now "old father, old brickmaker," a reference to the final lines of A Portrait of the Artist as a Young Man by James Joyce (286). Joyce draws upon mythology to juxtapose craftsman Daedalus (who is an "old father, old artificer") with his son Icarus, who flies too close to the sun in his search for freedom. ${ }^{11}$ Smith, who studied Joyce for her doctoral dissertation, invokes the tension between fathers and their children. George, Francescho, and Icarus all desire freedom from structure, particularly domestic structures. It's no coincidence that each of their fathers works with construction and buildings: one is a chimney inspector, the second a mason, and the third a carpenter. Each of their children attempts to push beyond the structures that protect, contain, even entrap or imprison them. What's more, each child later wishes to return. For Francescho, the return is painful. He finds his father sitting at the kitchen table from his childhood and recalls "there was written a list of names on the wood of the table : the list went all down the long side of it where we'd sat and eaten as children" (287). ${ }^{12}$ His father is going through the list and absolving each person of the debts

\footnotetext{
${ }^{11}$ Smith also references the myth of Daedalus and Icarus in George's section of the novel, where George and H use the word "minotaur" instead of "monitor" (85). According to the myth, Daedalus builds an underground labyrinth to trap the minotaur. Thus, Smith again invokes the dichotomy between freedom and confinement.

${ }^{12}$ Smith often uses colons instead of periods to connect sentences in Francescho's section. Readers learn that this linguistic move is a nod to Francescho's mother, who had a "habit of putting these 2 dots between clauses where a
} 
owed to him. The table is thereby no longer used to nourish his family, and his father is no longer conducting business for profit. The image is distantly familiar to Francescho, but it is distorted and unexpected. Reality has ruined his memory of home. Therefore, Francescho is intrigued by forgetting — by becoming roofless — as he believes "purgatorium is a state of troubling memory or the knowledge of a home after home is gone, or of something which you no longer have in a world which you recognize to be your own but in which you are a stranger and of which you can no longer be a part" (284). He is distressed by memories of his deceased father and the childhood home to which he cannot return. Consequently, he is willing to let the memory ritual leave him "open like a brand-new not-yet-lived-in-home" (283). He will simultaneously become a new dwelling and forget his past. Instead of facing his pain, Francescho attempts to escape by erasing it entirely.

Unlike George, Francescho only longs for momentary rooflessness. He claims, "I might end up roofless and open for ever, no memories at all of anything ever again : what I would give, to forget everything" (284). However, he recognizes that the idea of rooflessness is temporary. Once he releases his painful memory, the roof will return. He confirms this aspect of the ritual by asking Barto:

And those same old rooftiles, I said, hoist themselves off the ground again all at once, all the tiles that haven't broken and all the little broken bits, both, and they fly up like a skyful of stiff wingless birds back up to the open roof of me where they fix themselves back on, over and under all their old neighbors again? In exactly the same places?” (282).

breath should come" (286). Francescho notes that this habit has become his own. Thus, on the one hand, the punctuation connects Francescho to his mother. On the other hand, it transforms the words on the page into a visual image, as sentences resemble bricks laid next to one another. These sentences build Francescho's section of the novel. 
Smith once more entwines architecture and nature by making the rooftiles birds, and by likening the rooftiles to wingless birds, the tiles become both charmed and cursed — charmed because they are able to fly without wings and cursed because once they fix themselves back onto the roof, they are trapped. The rooftiles will not be removed again. Francescho's memories can be examined in a similar manner: they are both powerful and painful. If the ritual is successful, his memories will once again assemble like rooftiles, but the memory of his last visit with his father will remain lost. Yet, like Icarus's flight, there is danger to such an escape attempt. The memories may not land in "exactly the same places" signifying that Francescho could be a different person without the memory of his father-his blueprints would be redesigned. Moreover, Icarus's wings melt when they are warmed by the sun; his transformation into a wingless bird becomes fatal. By alluding to this myth, Smith positions rooftiles ("stiff wingless birds") as dangerous, and possibly destructive, objects.

\section{The novel as dwelling}

If Ali Smith is an architect, as I proposed earlier, then she designs a hidden room within How to Be Both. There is a story nestled between the two narratives - a story existing on the original blueprints for the novel, but one readers may overlook. Envision the text as a dwelling with two rooms, one each for George and Francescho. As noted at the beginning of my essay, these rooms are hardly separate or concrete. This porousness takes the form of the reciprocal frame narrative. In one instance, George theorizes this permeability in terms of the home and, curiously, as a kind of synesthesia: "Like, say you wake up one morning to the noise of someone along the road having work done on his or her house and you don't just hear the drilling happening, you feel it in your house, though it's actually happening several houses away" (14). George's slippage between hearing and feeling suggests a contiguous relationship between these 
two senses. She ultimately feels the unknown house under construction, just like she does when $\mathrm{H}$ leaves and the residence becomes deaf and hard. I would like to suggest that this house is actually Francescho's section of the novel. To explain, the construction noise in the passage is reminiscent of Francescho's memory ritual, during which he attempts to reassemble metaphorical roof tiles. I propose that George feels this struggle, this proverbial home construction, because Francescho's story is actually the result of George's school project about sympathy and empathy. In other words, George feels Francescho's story because Francescho's grief is inspired by her own. Smith asks readers to consider the possibility that the characters' histories are influenced by each other.

Francescho's narrative brims with clues that it is, in fact, embedded within George's imagination; it is one component of the reciprocal frame narrative, or a story within a story. Francesco del Cossa was a real Italian Renaissance artist, yet little is known about the painter. Readers learn "the thing it always says about him, in the hardly-anything-there-is when you look him up, is that very little is known about him" (116). When George and her mother visit Italy to view del Cossa's paintings, George asks if women artists contributed to frescos like Francescho's. Her mother's reply is telling, and rich with metahistorical possibilities: "It's pretty unlikely that women worked on much that's extant, certainly on anything we saw today. Though if I had to, I don't know, write a paper about it or try to make a thesis about it, I could make a pretty good one" (95). Her mother later adds, "I could make a reasonably witty argument for [Francescho's painting's] originator being female, if I had to" (96). These comments foreshadow George's school project with H. H suggests researching Francescho "precisely because there's so little known about him" and "they can make a great deal of it up and not be marked wrong because nobody will know either way" (Smith 118). George agrees, and the project, which imagines Francescho as a woman passing as a man, becomes a memorial of sorts to her mother, 
an extension of the photo shrine above her bed. She comments that it is "exactly the kind of stunt her mother would pull" (120). Indeed, Smith scatters signs that we should pay attention to this historiography, that George (re)writes del Cossa's backstory. Elizabeth Anker studies the novel through a postcritical lens and argues that Smith's characters create "scenes of interpretationscenes indelibly marked by academic criticism and theory" (23). In other words, George critically crafts Francescho's history, a history heavily influenced by Carol.

George is haunted by Francescho and Carol, whose histories are spun around each other. As Anker observes, "the narrative establishes noteworthy parallels between del Cossa and 'George's mother' (her designation in the section of the novel focalized through George's viewpoint)" (23). Readers might understandably assume that Francescho is Carol's double. Anker notes, for instance, "noteworthy parallels" between the characters and across the novel's sections (23). For example, both engage in relationships with women; both die young of similar causes. While this reading is compelling, more interesting, and more relevant to my argument, is the possibility that Francescho is a double for George, who designs Francescho's past with her mother in mind. Both George and Francescho attempt to navigate adolescence without their mothers, and both characters have contemptuous relationships with their fathers. Furthermore, the language of Francescho's section suggests George penned the narrative. Consider the following scene in which George and H discuss Francescho's diction:

He'd speak like from another time, H says. He'd say things like ho, or gadzooks, or egad.

I don't think they knew about the word ho...George says. (118)

The first words of Francescho's narrative read, "Ho this is a mighty twisting thing" (161). Twisted, indeed. 
Considering this historiography, what can we learn about George from Francescho's section of the novel? Recall that in a climactic scene, Francescho partakes in a memory ritual as a means to discard a recollection of his deceased father. George, too, is particularly concerned with memories, asking both her father and Mrs. Rock, "Do you think, when we die, that we still have memories?" (13). She poses this question after Carol dies, expressing that she is as equally concerned with being remembered as she is with remembering her mother. Memories are perhaps the key to unlocking the novel's enigmatic fascination with roofs. Earlier we saw how dwellings, specifically roofs, can function in paradoxical ways, protecting and stifling in equal measure. What if memories worked in a similarly paradoxical fashion? In George's example, her memories of her mother, specifically photographs, are both healing and hurtful. If George penned Francescho's story, then we know that George is thinking about how to remove a painful recollection of a parent - though at the same time, she clings to these memories and hopes to be remembered. Smith, therefore, in a characteristic move, keenly portrays the intricacies of grief.

In a world of lost art and frescos, Smith layers Francescho's story like a palimpsest. Why does she build this multi-dimensional space? That is, why make Francescho's story a standalone narrative and a history that George has rewritten? Smith playfully finds new, smart ways to design the written word. By folding George's and Francescho's narratives together, Smith urges readers to dwell within the novel to decode the text — to cross the threshold from reality to narrative. Indeed, Smith is renowned for her "fascination with liminal boundaries between reality and fiction" (Germanà and Horton 4). How do we cross this threshold? In his reading of Joycean fiction, Paul Saint-Amour contemplates "readerly altitude"-an instance where the reader hovers over the page (21). "We discover an 'inside' only available from above," he contends. Studying the roof is one entry point into How to Be Both. From this vantage, looking down at the page and the roof, readers can enter the novel from above, and in doing so, alternate between residing 
within the framework of the text and stepping back to reality to process the content. By understanding how Smith constructs Francescho's narrative, we are better able to understand George's grief and the empathic function of literature.

\section{Conclusion}

Given the rich and extensive architectural conceits in How to Be Both, it is indisputable that Smith forms George and Francescho around physical structures. Smith is a worldbuilderinterlinking narrative with bricks and shingles. In one instance, she writes, "[George] is not a girl. She is a block of stone. She is a piece of wall. She is something against which other things impact without her permission or understanding" (88). A block of stone and a piece of wall are both symbolic blank slates; the wall waits to be painted and the stone to be carved or assembled into structure. In a way, George takes on both of these tasks through her school project. She constructs a history in which Francescho will paint the wall and his father will build with the block of stone. George is, in effect, the raw material of Francescho and his father. To use Smith's words, these "other things" (or, these fifteenth-century characters) impact George "without her permission," as if she is compelled to write Francescho's narrative, even if she does not fully understand it. She likely does not realize how much of her own life she infuses in these characters. As I have argued, Smith emmeshes architecture with the DNA of her protagonists. Of all the architectural references in the novel, I suggest the attention to roofs is one of the most intriguing parallels between the two main characters.

For George and Francescho, rooflessness represents freedom; and while there is most certainly a pun about raising the roof here, the outcome is not entirely celebratory. At first glance, neither George nor Francescho become roofless. George admits to her father that her room has a leak because she "felt mean"- as though it was unkind to prioritize her grief over her 
father's grief (140). This guilt mirrors Francescho's guilt about leaving home, leaving his father. In an attempt to alleviate his conscience, Francescho participates in the (ultimately unsuccessful) memory ritual; he pretends to have lost his memories, but he cannot lie about such a loss for long. The question, then, is: why do these characters retain their roofs? I propose that Smith implies attempts to change the bereavement process are futile. As readers, we grieve alongside George and Francescho as they mourn their parents and face memories that have become intolerable. We know that there is no way to hasten this grief. Still, by shining light on the characters' desire to do so, Smith illuminates what it is like to mourn "for real"- - a theme she addresses in many of her novels (Smith 137). She gently signals to readers that we must embrace our mortality and all that it entails.

Yet, when we look a layer deeper — that is, when we look at George's story within Francescho's half of the novel — a roof does indeed collapse. While George's bedroom ceiling remains intact, she discards rooftiles outside the boundaries of her narrative. To explain, the spectral Francescho watches George and $\mathrm{H}$ in the lofted bedroom. George has constructed a wall of pictures, where "the picture has been made to become a brick" (308). Significantly, the present moment with $\mathrm{H}$ outweighs the memories in the pictures, causing Francescho to ask, "The pictures of - what are they of, again?" (309). In this way, Smith privileges the medium of the photos over the content; she privileges the bricks that make the wall, and memories and grief become secondary, if only for a moment. This move advises readers to watch this wall, to pay attention to these bricks. The girls move from careful to carefree; they start by handling the picture wall with caution and ultimately wrap themselves in it, spinning toward each other. As Francescho notes, “They don't just meet, they collide : at which the paper wall breaks and as it comes apart its brick-shapes fly off like rooftiles and the girls hit the floor together in each other's 
arms" (310 emphasis mine). In finding solace in H's company, George shakes off heavy bricks, rooftiles, pictures — even memories.

Ultimately, we can read the roof as a metaphor for space. For instance, Smith writes, "George's room, given enough time, enough bad weather and the right inattention, will open to the sky" (13). Likewise, the aim of Francescho's memory ritual is to attain a moment "like before you were born. Like just newborn. Open to everything. Open to the weather. Everything new" (282). In both passages, the characters crave the open sky and a proximal intimacy with the weather. In this way, I suggest Smith hints at the necessity of vulnerability — vulnerability to the changing climate, to others, to our own aspirations. George finds such space and vulnerability through her writing. Like Icarus, she is looking for an escape. Pen in hand, George flies away from rainy London and travels back in time to the 1400s, conjuring another world on paper. She revels in imaginative freedom and has Francescho navigate the world in a way she cannot; he leaves his familial responsibilities and follows his passions rooted in both art and relationships. What's more, this writing project stems from a shared assignment with $\mathrm{H}$. Like being privy to the leaking roof, $\mathrm{H}$ is granted a glimpse inside George's imagination. George's roof does not collapse when she is isolated in her bedroom; it collapses when she makes a change in her solitary mourning and deliberately moves toward $\mathrm{H}$.

Like characters imagining space beyond the roof, How to Be Both urges readers to transcend the established limits of the traditional novel, in an act of reading that Anker describes as "the onus to interpret: to unravel and decode the enigma of its perplexing organization and whatever it might symbolize" (21). While the house is a static structure, Smith encourages movement by drawing the reader's attention to thresholds - moving in and out of the house through the roof, meandering between the two sections of the novel. The reader, all the while, has agency in this navigation. At an art museum in Italy, Carol says, "It's as if that map they 
gave us is nothing to do with the actual experience of being here" (54). The same can be said about How to Be Both; the sections of the book suggest that there are two unique stories. By entangling these narratives, Smith emboldens readers to explore the novel and to question its form. After all, “there's always more to see, if you look” (Smith 122). 
Works Cited

Benfey, Christopher. “'How to Be Both,' by Ali Smith.” The New York Times, The New York Times, 31 Dec. 2014, www.nytimes.com/2015/01/04/books/review/how-to-be-both-byali-smith-review.html.

Davies, Ben. "The Complexities of Dwelling in Ali Smith's There but for the." Critique: Studies in Contemporary Fiction, vol. 58, no. 5, 2017, pp. 509-520.

Germanà Monica, and Emily Horton. Ali Smith: Contemporary Critical Perspectives. Bloomsbury Academic, 2013.

Johnson, Allan. “'The Doors Would Be Taken off Their Hinges': Space, Place and Architectural Absence in Virginia Woolf.” English Studies, vol. 97, no. 4, 2016, pp. 412-419.

Korosec-Serfaty, Perla. "The Home from Attic to Cellar.” Journal of Environmental Psychology, vol. 4, 1984, pp. 303-321.

Rosner, Victoria. Modernism and the Architecture of Private Life. Columbia University Press, 2008.

Paul K. Saint-Amour. "Over Assemblage: Ulysses and The Boite-En-Valise From Above." European Joyce Studies, vol. 15, no. 1, 2003, pp. 21-58.

Smith, Ali. How to Be Both. Anchor Books, 2015.

Spurr, David Anton. Architecture and Modern Literature. University of Michigan Press, 2012.

"Stave, n.1." OED Online, Oxford University Press, June 2020, www.oed.com/view/Entry/189390.

"Stave, v." OED Online, Oxford University Press, June 2020, www.oed.com/view/Entry/189393.

Weaver, Milly. "Reading Words alongside Images: Ali Smith and Visual Portraiture." Interdisciplinary Literary Studies, vol. 20 no. 4, 2018, p. 527-548. 